\title{
Effects of understory removal on root production, turnover and total belowground carbon allocation in Moso bamboo forests
}

\author{
Xiaolu Tang ${ }^{(1)}$, Shaohui Fan ${ }^{(1)}$, \\ Lianghua Qi ${ }^{(1)}$, Fengying Guan ${ }^{(1)}$, \\ Guanglu Liu ${ }^{(1)}$, Manyi Du ${ }^{(2)}$
}

\begin{abstract}
Although the role of roots has been highlighted in carbon and nutrient cycles in forest ecosystems, root production, turnover and total belowground carbon allocation (TBCA) under different management regimes in Moso bamboo forests have not been determined to date. In this study, sequential soil cores were collected at two soil depths $(0-20 \mathrm{~cm}$ and $20-40 \mathrm{~cm})$ to assess the effects of understory removal on root production, turnover, and TBCA in Moso bamboo forests in subtropical China. A total of 1080 sequential soil cores were collected from April 2011 to March 2012. Understory removal significantly reduced fine root biomass and production for both soil layers $(p<0.05)$. Total fine root biomass was $781.9,419.2$, and $638.7 \mathrm{~g} \mathrm{~m}^{-2}$ for an unmanaged stand (stand I), pesticide-treated stand (stand II), and hand-weeded stand (stand III), and fine root production was $467.5,235.1$, and $321.6 \mathrm{~g} \mathrm{~m}^{-2} \mathrm{a}^{-1}$, respectively. Understory removal did not significantly affect fine root turnover $\left(0.5-0.6 \mathrm{a}^{-1}\right)$. Fine root turnover showed a strong relationship with fine root production, but not with fine root biomass, indicating that fine root production was the main driver of fine root turnover. TBCA calculated from the component cumulative approach was in order of stand I $\left(481.9 \mathrm{~g} \mathrm{C} \mathrm{m}^{-2} \mathrm{a}^{-1}\right)>$ stand II $\left(457.7 \mathrm{~g} \mathrm{C} \mathrm{m}^{-2} \mathrm{a}^{-1}\right)$ $>$ stand III $\left(404.9 \mathrm{~g} \mathrm{C} \mathrm{m}^{-2} \mathrm{a}^{-1}\right)$, though the differences were not statistically significant $(p>0.05)$. However, TBCA calculated from the mass balance approach showed a reverse trend compared to the component cumulative approach. The TBCA of stand III was significantly higher than that of stand I and stand II $(p<0.05)$, demonstrating that the belowground process is complex and standardizing the method of estimation of TBCA is extremely important in global carbon cycle modeling.
\end{abstract}

Keywords: Fine Root, Coarse Root, Production, TBCA, Moso Bamboo Forest
(Vogt et al. 1995). In contrast, fine roots are a major contributor to the carbon and nutrient cycles due to their short life span and rapid turnover, although they represent a small part of the total stand biomass in forests (Gill \& Jackson 2000, Yuan \& Chen 2013). Fine root production contributes to $33-70 \%$ of annual net primary production (Jackson et al. 1997, Vogt et al. 1995). However, compared to aboveground production, little is known about the contribution of roots to soil carbon (Finér et al. 2011a). This is partly due to methodological difficulties, the labor-intensity of the research, and internal and external factors
(1) Key Laboratory of Bamboo and Rattan Science, International Centre for Bamboo and Rattan, Wangjing, Chaoyang District, Beijing 100102 (China); (2) Experimental Center of Forestry in North China, Chinese Academy of Forestry, No. 1 Shuizaxilu, Mentougou, Beijing 102300 (China)

@ Shaohui Fan (fansh@icbr.ac.cn), Fengying Guan (guanfy@icbr.ac.cn)

Received: Apr 13, 2015 - Accepted: Aug 17, 2015

Citation: Tang X, Fan S, Qi L, Guan F, Liu G, Du M (2015). Effects of understory removal on root production, turnover and total belowground carbon allocation in Moso bamboo forests. iForest 9: 187-194. - doi: 10.3832/ifor1674-008 [online 2015-11-20]

Communicated by: Arthur Gessler that greatly affect root biomass and production (Majdi et al. 2005, Vogt et al. 1995). Fine root biomass, production, and turnover are sensitive to environmental changes, such as temperature, precipitation, soil properties, and stand age, as well as management practices (Finér et al. 2011a, b, Gill \& Jackson 2000, Pregitzer et al. 2000). Consequently, these changes could directly impact ecosystem carbon sequestration under a changing climate (Berhongaray et al. 2013). Hence, a better understanding of fine root production and turnover could improve our capability to model future changes in the carbon cycle and predict the response of terrestrial ecosystems to future climate change (Yuan \& Chen 2013). Intensive studies on fine root production and turnover have been conducted, although the progress is slow due to practical methodological problems ( $\mathrm{Fi}$ nér et al. 2011a, 2011b, Gill \& Jackson 2000, Pregitzer et al. 2000). These studies cover different forest types, stand ages, stand densities and basal areas relating to environmental factors, mainly air temperature, precipitation, geographic location, elevations and soil properties (Finér et al. 2011a, 2011b, Gill \& Jackson 2000, Yuan \& Chen 2010). However, knowledge of the controls and mechanisms of fine root production, 
turnover and dynamics remain limited (Brassard et al. 2009, Yuan \& Chen 2010).

Compared to fine root production and turnover, total belowground carbon allocation (TBCA) is a more direct indicator of the magnitude of belowground carbon allocation and the contribution of root production to TBCA. TBCA represents as much as $21-61 \%$ of total gross primary production (Chen et al. 2007). TBCA can even exceed aboveground net primary production and litter production, and provide the primary source of detritus carbon to mineral soil (Law et al. 1999, Ryan et al. 1997). Despite the significance of TBCA in the carbon budget of terrestrial ecosystems has been highlighted, controls and mechanisms of TBCA are poorly understood (Giardina \& Ryan 2002). For example, direct measurement of TBCA are still difficult due to complex belowground processes and the partitioning of soil respiration components (Hanson et al. 2000). Hence, compared to the direct measurement of TBCA, indirect measurements such as the mass balance approach (Raich \& Nadelhoffer 1989) are more commonly used (Chen et al. 2005, Davidson et al. 2002). Studies on TBCA have been performed in Chinese fir plantations (Chen et al. 2005, 2008), a Castanopsis kawakamii forest (Chen et al. 2005), a Metrosideros polymorpha-dominated forest (Raich 1998), a Eucalyptus saligna forest (Giardina \& Ryan 2002) and a Pseudotsuga menziesii forest (McDowell et al. 2001). To our knowledge, to date, TBCA has not been determined in a Moso bamboo (Phyllostachys heterocycla [Carr.] Mitford cv. Pubescens) forest managed by understory removal, although there has been one report on fine root production and turnover in Moso bamboo (Fan et al. 2009).

Bamboo forests are an important forest type in Southern China, and Moso bamboo is the most important bamboo species, accounting for $70 \%$ of the total area of bamboo forests in China (State Forestry Administration 2014). In the last few decades, driven by the good price and sustainable forest development policies, the Moso bamboo forest area has expanded rapidly (Wang et al. 2008), increasing from 1.5 million ha in 1957 to 5.38 million ha in 2008 (Fu
2001, State Forestry Administration 2014). This area accounts for over $90 \%$ of Moso bamboo forests in the world (Zhou et al. 2011). The growth rate of Moso bamboo is very high; a newly emerged culm can grow up to $119 \mathrm{~cm}$ within 24 hours, and to $24 \mathrm{~m}$ high within 40-50 days (Fu 2001). Moso bamboo forests also play an important role in the regional, national, and even global carbon cycle because the carbon stock in bamboo forest comprises $11 \%$ of the total carbon stock of China's forest ecosystems (Chen et al. 2009). To improve stand production and maximize economic benefits, intensive management, such as regular understory removal, tillage, and fertilization, are becoming popular (Liu et al. 2011). These practices have been reported to reduce soil microbial diversity (Xu et al. 2008), increase soil carbon mineralization (Zhou et al. 2006), and change the soil chemical composition ( $\mathrm{Li}$ et al. 2013). However, there is a lack of information on the effects of understory removal on root production and turnover.

The objectives of this study were to: (1) investigate the effects of understory removal on the allocation pattern of root biomass, production, root turnover, and TBCA; (2) determine the relationships between root production and root biomass and TBCA; and (3) determine whether different methodological approaches affect TBCA estimation.

\section{Materials and methods}

\section{Study area}

The study area is located in Dingmushan Forest Farm $\left(29^{\circ} 27^{\prime} \mathrm{N}, 113^{\circ} 57^{\prime} \mathrm{E}\right)$ in Chibi city, Hubei Province, China. The area has a typical subtropical monsoon climate with an average precipitation of $1251-1608 \mathrm{~mm}$ per year with great seasonality: $52 \%$ of the precipitation occurs during the flood season (May to August). The highest annual precipitation was $2678 \mathrm{~mm}$ in 1954 and the lowest was $910 \mathrm{~mm}$ in 1968. The mean annual temperature is $16.9^{\circ} \mathrm{C}$, with the highest temperature in July and the lowest in January. There are 247-261 frost-free days in this area.

The forest farm is owned by the local go-

Tab. 1 - Summary of the characteristics of studied stands. I, II and III represent control, pesticide-treated and hand-weeded stand, respectively.

\begin{tabular}{lccc}
\hline Variables & I & II & III \\
\hline Average elevation $(\mathrm{m})$ & 161 & 112 & 168 \\
Slope (deg) & 16 & 12 & 17 \\
Average height $(\mathrm{m})$ & 11.1 & 13.1 & 12.3 \\
Average Diameter $(\mathrm{cm})$ & 8.2 & 8.3 & 8.8 \\
Soil bulk density $\left(\mathrm{g} \mathrm{cm}^{-3}\right)$ & 1.28 & 1.3 & 1.14 \\
Total porosity $(\%)$ & 45.21 & 46.99 & 45.72 \\
Soil carbon content $\left(\mathrm{g} \mathrm{kg}^{-1}\right)$ & 26.41 & 25.86 & 23.72 \\
Total N $\left(\mathrm{g} \mathrm{kg}^{-1}\right)$ & 1.33 & 2.03 & 1.12 \\
Total K $\left(\mathrm{g} \mathrm{kg}^{-1}\right)$ & 9.68 & 15 & 12.7 \\
Total P $\left(\mathrm{g} \mathrm{kg}^{-1}\right)$ & 0.32 & 0.37 & 0.31 \\
Understory $\left(\mathrm{g} \mathrm{m}^{-2}\right)$ & 68.8 & 25.9 & 80.8 \\
Aboveground biomass $\left(\mathrm{g} \mathrm{m}^{-2}\right)$ & 2857.7 & 4006.1 & 3421.4 \\
Litter $\left(\mathrm{g} \mathrm{m}^{-2}\right)$ & 401.8 & 384.9 & 246.1 \\
\hline
\end{tabular}

vernment. In the 1960s, pure Moso bamboo forests were planted. In the 1990s, due to a salary reform of the government, the local residents of the farm rented the Moso bamboo forests for their daily income. In order to improve their economic benefits, management practices have been conducted since the 1990 s by removing the understory every year and by reclamation every three years according to local residents' descriptions. The main understory species are Liriodendron chinense Hemsl., Rhus chinensis Mill., Loropetalum chinense (R. Br.) Oliv., Smilax glabra Roxb., Castanea seguinii Dode., Castanopsis tibetana Hance, and Castanopsis tessellata Hick. et A. Camus. More details on stand characteristics are given in Tab. 1.

\section{Study design}

Two Moso bamboo stands managed by the application of pesticides (stand II) and hand-weeded (stand III) and one stand without any management (stand I) were selected. The application of pesticides, a mixed solution of Roundup and Jialijia at a concentration of $5 \%$, was conducted on sunny days every July since 2000 to remove shrubs and herbs. The understory shrubs and herbs died days after pesticide application. Weeding was conducted twice a year in May and September since 2000 by hand without any heavy machinery. In March 2011, three $20 \times 20 \mathrm{~m}$ plots were established in each of the selected stands. There was a $10 \mathrm{~m}$ buffer zone between the two adjacent plots.

\section{Stand inventory}

In each inventory plot, diameter at breast height ( $\mathrm{DBH}, 1.3 \mathrm{~m})$ and age of all bamboos were measured to the nearest $0.1 \mathrm{~cm}$ with a diameter tape. The age was recorded based on visual examination of the culm color, eyelash on cycle of culm sheath, powder under cycle of culm sheath, and the base of the culm sheath (Zhang et al. 2014). The age was expressed in "du", which reflects the growth characteristics in "on-year" and "off-year" in Moso bamboo forests. In an "on-year", more than $90 \%$ of new shoots are produced, followed by a few new shoots in an "off-year", because Moso bamboo produces new shoots at two-year intervals (Zhou et al. 2011). One "du" is 1-2 years, and consequently, 2, 3, and 4 "du" correspond to $3-4,5-6$, and 7-8 years, respectively (Fu 2000). The aboveground biomass (AGB) of individual bamboo (including culms, branches, and leaves) was estimated using eqn. 1 (Zhou et al. 2010):

$A G B=747.784 D B H^{2.771} \cdot\left(\frac{0.148 \cdot A}{0.028+A}\right)^{5.555}+3.772$

where $A G B$ is the aboveground biomass; $A$ is the age ("du" - Fu 2000, Zhou et al. 2010); and $D B H$ is the diameter at breast height $(1.3 \mathrm{~m})$ in $\mathrm{cm}$.

Therefore, the aboveground net primary production (ANPP) of bamboo was the 
sum of the production of the newly established bamboos, 2, 3, and 4 "du" bamboos, and the understory. For simplicity, 0.5 was used as the carbon concentration to convert biomass to carbon (Zhou \& Jiang 2004a).

The understory was harvested in three $1 x$ $1 \mathrm{~m}$ subplots in each plot. Monthly litter input was collected by three $1 \times 1 \mathrm{~m}$ collectors set in a similar equilateral triangle shape in each plot. All samples were dried to a constant weight at $65^{\circ} \mathrm{C}$. The annual biomass of the understory was equal to the annually formed biomass because the understory was newly formed every year.

\section{Root sampling and net primary production}

The roots were collected by sequential soil cores ( $8 \mathrm{~cm}$ in diameter) in the middle of each month from April 2011 to March 2012. Five soil cores were randomly selected in each plot and divided into two layers: $0-20 \mathrm{~cm}$ and $20-40 \mathrm{~cm}$, because most of the bamboo roots were distributed above $40 \mathrm{~cm}$ (Tang et al. 2012). A total of 1080 soil sequential cores were collected. The roots were manually washed to remove soil in flowing water. Roots with a diameter smaller than $2 \mathrm{~mm}$ were defined as fine roots in accordance with widely used criteria (Vogt et al. 1995, Bauhus \& Bartsch 1996, Ma et al. 2012), whereas roots with a diameter larger than $2 \mathrm{~mm}$ were defined as coarse roots. In the laboratory, root samples were dried to a constant weight at 65 ${ }^{\circ} \mathrm{C}$ and weighed to the nearest $0.01 \mathrm{~g}$. The carbon concentration of roots was determined using the $\mathrm{K}_{2} \mathrm{Cr}_{2} \mathrm{O}_{7}-\mathrm{H}_{2} \mathrm{SO}_{4}$ wet oxidation method (Zhang et al. 1999). The fine root NPP was estimate by a maximum-minimum approach (Brunner et al. 2013, McClaugherty et al. 1982 - eqn. 2, eqn. 3):

$$
\begin{aligned}
N P P_{f r} & =B_{\text {max }}-B_{\text {min }} \\
R T & =\frac{N P P_{f r}}{B_{\text {mean }}}
\end{aligned}
$$

where $N P P_{\mathrm{fr}}$ is the fine root net primary production $\left(\mathrm{g} \mathrm{m}^{-2}\right) ; B_{\max }$ and $B_{\min }$ are the maximum and minimum fine root biomass, respectively $\left(\mathrm{g} \mathrm{m}^{-2}\right) ; R T$ is the fine root turnover rate $\left(a^{-1}\right)$; and $B_{\text {mean }}$ is the mean fine root biomass $\left(\mathrm{g} \mathrm{m}^{-2}\right)$.

Because $95 \%$ of the biomass increment results from 1 "du" bamboos in Moso bamboo forests (Tang et al. 2015), and there is no diameter and height increment in 2, 3, and 4 "du" bamboos (Fu 2000), the coarse root production of 2,3 , and 4 "du" bamboo was ignored. Therefore, the production of coarse roots was estimated by considering the ratio of the above- and belowground biomass and the difference between new established belowground NPP and fine root $N P P$. When calculating the TBCA, the production and biomass were converted to carbon considering the corresponding carbon content.
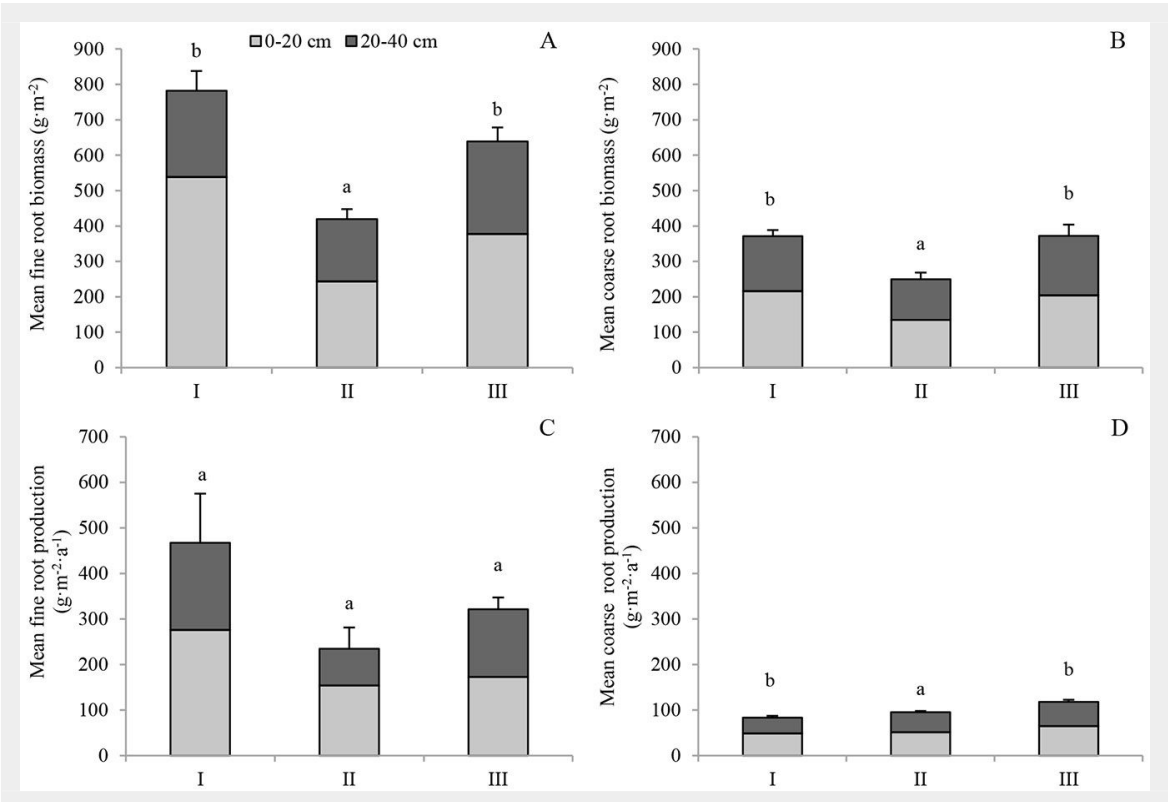

Fig. 1 - Root biomass and production at 0-20 cm and 20-40 cm depths. Different letters above the error bars indicate the significant difference among stands $(p<0.05)$ for total stand root biomass or production over $0-40 \mathrm{~cm}$. The results of the comparison among different managements in the same layer are shown in Tab. 2. I, II and III represent the control, pesticide-treated and hand-weeded stand, respectively.

\section{TBCA}

The component cumulative approach (Chen et al. 2005) and the mass balance approach (Raich \& Nadelhoffer 1989) were used to estimate the TBCA. The component cumulative approach can be expressed as follows (eqn. 4):

$$
T B C A=N P P_{f r}+N P P_{c r}+R_{r}
$$

where $R_{\mathrm{r}}$ is the annual root respiration ( $\mathrm{g} \mathrm{C}$ $\mathrm{m}^{-2} \mathrm{a}^{-1}$ ), taken from the results published by Tang (2012); $N P P_{\mathrm{cr}}$ is the coarse root production ( $\left.\mathrm{g} \mathrm{C} \mathrm{m}^{-2} \mathrm{a}^{-1}\right)$; and other variables are as explained above.

The mass balance approach was first proposed by Raich \& Nadelhoffer (1989) based on the assumption that changes in total organic carbon stock and annual input from aboveground and belowground are equal to the annual respiration of soil decomposers in nearly steady-state ecosystems. That is, the carbon change of the mineral soil, roots, and litter is assumed to be zero, so TBCA can be expressed as (Raich \& Nadelhoffer 1989 - eqn. 5):

$$
T B C A=R_{s}-L F
$$

where $R_{\mathrm{s}}$ is the total soil respiration, taken from the published results of Tang (2012), and $L F$ is the litter carbon ( $\mathrm{g} \mathrm{C} \mathrm{m}^{-2}$ year ${ }^{-1}$ ).

\section{Statistical analysis}

Statistical analysis was conducted in $R$ 3.1.2 (R Core Team 2014). Two-way factorial ANOVA analysis was applied to examine the effects of management and soil depth on fine root biomass and production, and a Tukey's HSD test was used to determine the significance of multiple comparisons ( $a$ $=0.05$ ). The relationships between root production and biomass and TBCA were analyzed by linear regression.

\section{Results}

\section{Root biomass, production, and \\ turnover}

Root biomass and production varied greatly among stand managements and soil depths (Fig. 1A, Fig. 1B, Tab. 2). Both fine and coarse root biomass were higher in the upper layer $(0-20 \mathrm{~cm})$ and decreased with increasing soil depth. In $0-20 \mathrm{~cm}$, the annual mean fine root biomass of stand I

\begin{tabular}{|c|c|c|c|c|c|c|c|c|}
\hline \multirow{3}{*}{ Factor } & \multicolumn{4}{|c|}{ Fine root } & \multicolumn{4}{|c|}{ Coarse root } \\
\hline & \multicolumn{2}{|c|}{ Biomass } & \multicolumn{2}{|c|}{ Production } & \multicolumn{2}{|c|}{ Biomass } & \multicolumn{2}{|c|}{ Production } \\
\hline & $F$ & $p$ & $F$ & $p$ & $F$ & $p$ & $F$ & $p$ \\
\hline Management & 33.7 & $<0.001$ & 5.02 & 0.026 & 9.91 & 0.003 & 8.73 & 0.005 \\
\hline Depth & 77.42 & $<0.001$ & 3.99 & 0.069 & 9.24 & 0.010 & 10.61 & 0.007 \\
\hline Management $\times$ Depth & 14.41 & 0.001 & 0.38 & 0.689 & 0.81 & 0.468 & 0.25 & 0.783 \\
\hline
\end{tabular}
was $538.5 \mathrm{~g} \mathrm{~m}^{-2}$, which was significantly

Tab. 2 - Results of the two-way factorial ANOVA testing the effects of management and depth on fine or coarse root biomass and production. 
Fig. 2 - The relationship between mean fine root biomass and fine root production.

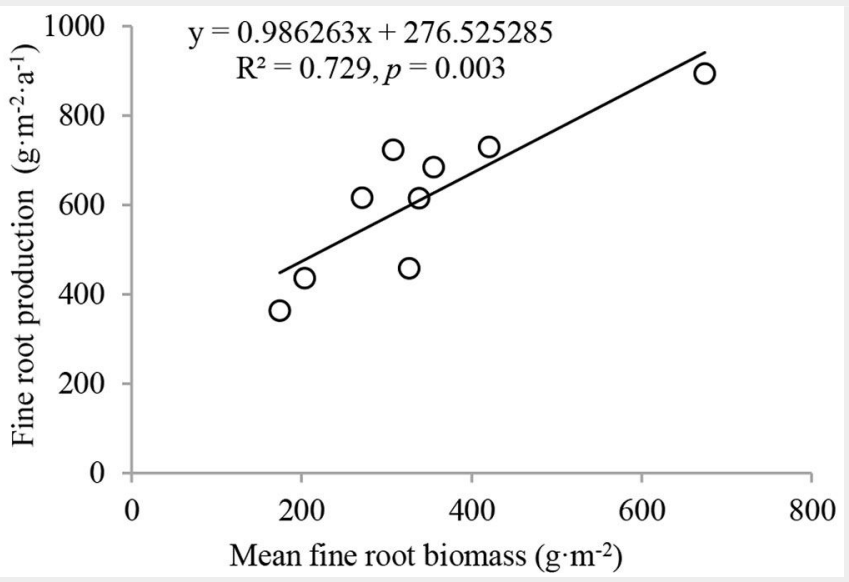

Fig. 3 - Effects of understory removal on fine root turnover. The same letter above the error bar indicates no significant difference among the stands $(\mathrm{p}<0.05) . \mathrm{I}$, II and III represent control, pesticide-treated and hand-weeded stand, respectively.

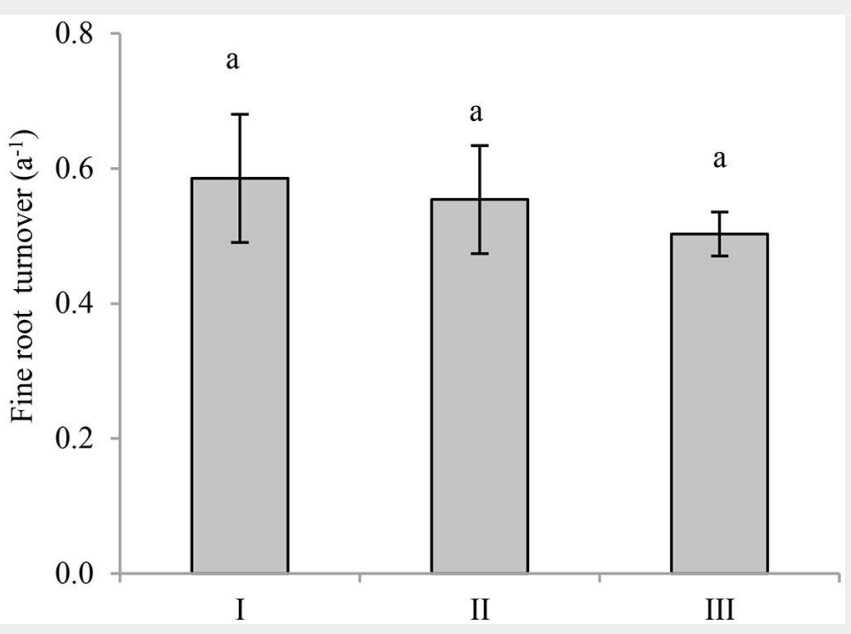

Fig. 4 - The relationship between fine root production and fine root turnover.

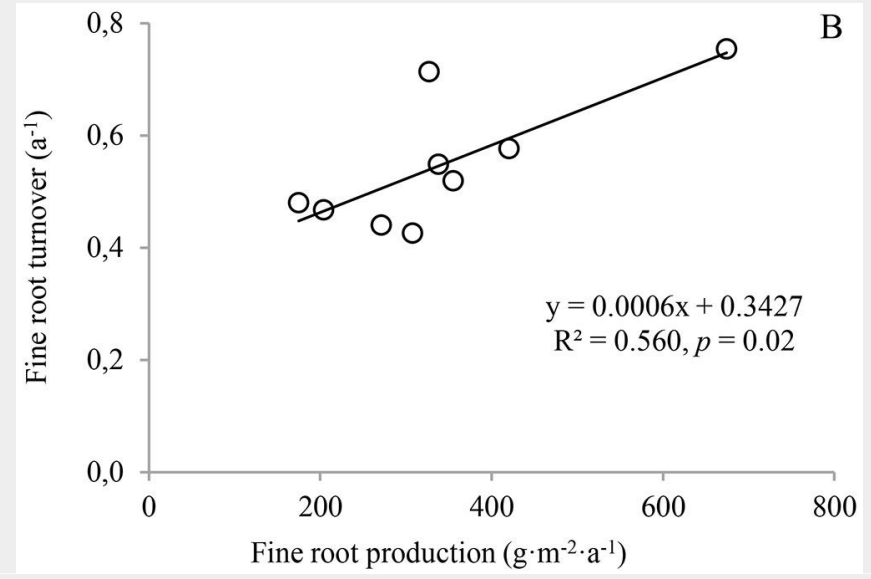

Fig. 5 - Effects of understory removal on total belowground carbon allocation. Different letters indicates significant difference among the stands ( $\mathrm{p}<0.05)$. I, II and III represent control, pesticide-treated and hand-weeded stand, respectively.

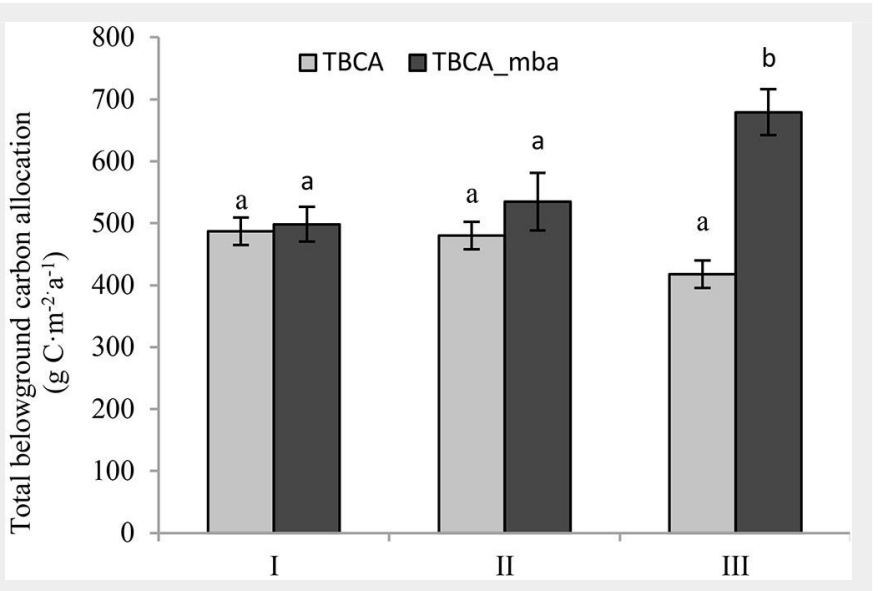

higher $(p<0.05)$ than that of stand II $\left(243.5 \mathrm{~g} \mathrm{~m}^{-2}\right)$ and stand III $\left(377.2 \mathrm{~g} \mathrm{~m}^{-2}\right)$. The difference in fine root biomass between stand II and stand III was statistically significant $(p<0.05)$. In $20-40 \mathrm{~cm}$, the fine root biomass of stand III was the highest (268.7 $\left.\mathrm{g} \mathrm{m}^{-2}\right)$, followed by that of stand I (243.5 g $\mathrm{m}^{-2}$ ) and stand II (175.6 $\left.\mathrm{g} \mathrm{m}^{-2}\right)$. In both 0-20 $\mathrm{cm}$ and $20-40 \mathrm{~cm}$ layers, mean coarse root biomass followed the same order: stand I > stand III > stand II. Total fine root biomass over $0-40 \mathrm{~cm}$ was $781.9,419.2$ and $638.7 \mathrm{~g}$ $\mathrm{m}^{-2}$ for stand I, stand II, and stand III, respectively, compared to $371.3,249.3$, and $372.1 \mathrm{~g} \mathrm{~m}^{-2}$, respectively for total coarse root biomass. Both fine and coarse root biomass of stand II were significantly lower than that of stand I and stand III. However, the interaction of understory removal and soil depth had no significant effect on coarse root biomass (Tab. 2).

Similarly, fine root production decreased with increasing soil depth (Fig. 1C). The fine root production of stand I was $276.0 \mathrm{~g} \mathrm{~m}^{-2}$ $a^{-1}$ in $0-20 \mathrm{~cm}$. It was significantly higher ( $p$ $<0.05)$ than that of stand II $\left(152.3 \mathrm{~g} \mathrm{~m}^{-2} \mathrm{a}^{-1}\right)$ and stand III (172.5 $\left.\mathrm{g} \mathrm{m}^{-2} \mathrm{a}^{-1}\right)$. A similar pattern of change was found for fine root production in $20-40 \mathrm{~cm}$. Fine root production differed with stand management or soil depth at a significant $(p<0.05)$ or marginally significantly $(0.05<p<0.1)$ level (Tab. $2)$. Compared to fine root production, coarse root production was much lower, ranging from $34.9 \mathrm{~g} \mathrm{~m}^{-2} \mathrm{a}^{-1}$ in $20-40 \mathrm{~cm}$ in stand I to $64.7 \mathrm{~g} \mathrm{~m}^{-2} \mathrm{a}^{-1}$ in $0-20 \mathrm{~cm}$ in stand III. Understory removal and soil depth had significant effects on coarse root production, but their interactions did not have significant effects on coarse root production. The total fine root production over $0-40 \mathrm{~cm}$ was $467.5,235.1$, and $321.6 \mathrm{~g} \mathrm{~m}^{-2} \mathrm{a}^{-1}$ for stand I, stand II, and stand III, respectively, compared to $83.6,95.1$, and $117.8 \mathrm{~g} \mathrm{~m}^{-2} \mathrm{a}^{-1}$ for coarse root production. Coarse root production in stand I was significantly lower than that of stand III over $0-40 \mathrm{~cm}(p<$ $0.05)$. A strong relationship was observed between fine root production and fine root biomass (Fig. 2).

Calculated fine root turnover (FRT) had a range of 0.5-0.6 $\mathrm{a}^{-1}$ for the three stands (Fig. 3), and the understory removal had no significant effect on FRT $(p=0.74)$. It was surprising that there was no significant relationship between FRT and fine root biomass, combining the significant positive correlation between FRT and fine root production ( $p=0.020$ - Fig. 4$)$, indicating that fine root production was the main determinant of FRT, rather than mean fine root biomass in Moso bamboo forests.

\section{Total belowground carbon allocation}

TBCA calculated from the component cumulative approach was $486.9 \mathrm{~g} \mathrm{C} \mathrm{m}^{-2} \mathrm{a}^{-1}$ for stand I, $480.0 \mathrm{~g} \mathrm{C} \mathrm{m}^{-2} \mathrm{a}^{-1}$ for stand II and $417.7 \mathrm{~g} \mathrm{C} \mathrm{m}^{-2} \mathrm{a}^{-1}$ for stand III (Fig. 5). There was no significant difference in TBCA among the three stands. However, TBCA calculated from the mass balance appro- 
ach showed a reverse pattern; it was highest in stand III, with a value of $679.2 \mathrm{~g} \mathrm{C}$ $\mathrm{m}^{-2} \mathrm{a}^{-1}$. This value was significantly higher $(p$ $<0.05)$ than that of stand I $\left(489.4 \mathrm{~g} \mathrm{C} \mathrm{m}^{-2}\right.$ $\left.\mathrm{a}^{-1}\right)$ and stand II $\left(534.9 \mathrm{~g} \mathrm{C} \mathrm{m}^{-2} \mathrm{a}^{-1}\right)$. Surprisingly, only the linear relationship between TBCA and fine root production was significant $\left(R^{2}=0.539, p=0.021\right.$ - Fig. 6$)$, and there was no relationship between TBCA and coarse root biomass and production $\left(R^{2}=0.002-0.021, p=0.708-0.861\right)$.

The ratio of TBCA/ANPP of stand I was 0.89 (Fig. 7), which was significantly higher than that of stand III (0.55), but not significantly different from that of stand II (0.78). Moreover, the ratio of belowground net primary production (BNPP) and TBCA in stand II (0.26) was significantly lower than that of stand I (0.46) and stand III (0.40).

\section{Discussion}

Fine root biomass, production, and fine root turnover

Understory removal is an important management practice to reduce resource competition between understory vegetation and the target timber output in Moso bamboo forests. This management tended to allocate more biomass to aboveground. Therefore, the AGB of bamboos in stand II and stand III were higher than that of stand I (Tab. 1). Although the increase in $A G B$ in the managed Moso bamboo forest could potentially increase the root biomass for production, the fine roots of the understory could contribute a remarkable amount to total root biomass and production, and the understory biomass in stand I was significantly higher than that in stand II (Tab. 1). Therefore, the fine root production of stand I was significant higher than that of stand II. As evidenced in poplar forests, the root production of the understory may equal or exceed the fine root biomass or production of the overstory (Berhongaray et al. 2013). However, in our study, we did not separate the fine roots of bamboo and herbs because they are extremely difficult to distinguish, as Moso bamboo is taxonomically a kind of herb. Therefore, we considered the root biomass of Moso bamboo and the understory as a whole, rather than separately. It is no doubt that the understory contributed a significant part to total fine root biomass and production (Berhongaray et al. 2013). No significant differences in root biomass and production were observed between stand I and stand III (Fig. 1). Because traditional hand-weeded just removed the aboveground portion of understory vegetation, which could regenerate, no differences were found in the root biomass and production compared to stand I. These results also highlight the importance of including the effects of stand management on fine root production in global carbon cycle modeling.

Fine root biomass ranged from 4.2 to 7.8 $t$ ha $^{-1}$, accounting for 6.8 to $13.9 \%$ of total

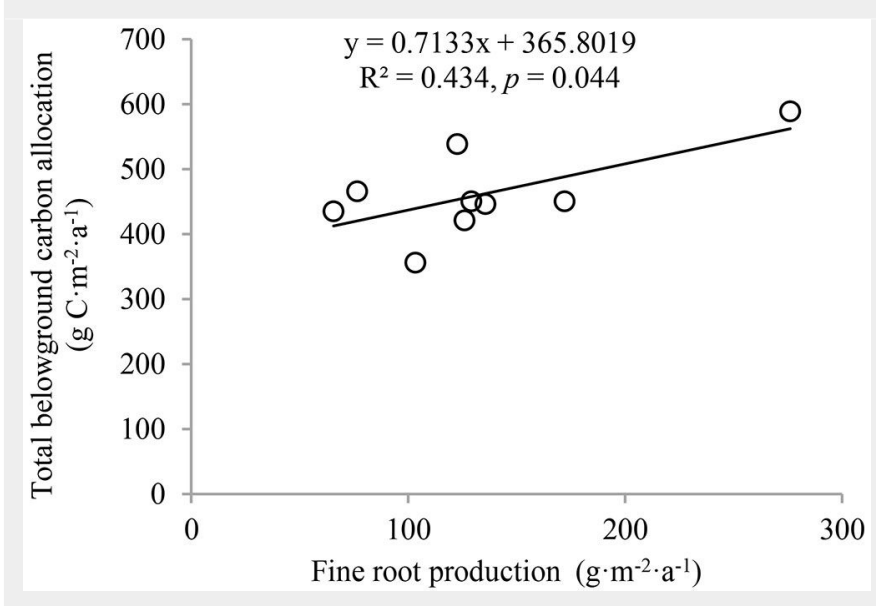

Fig. 6 - The relationships between total belowground carbon allocation and fine root biomass and production.

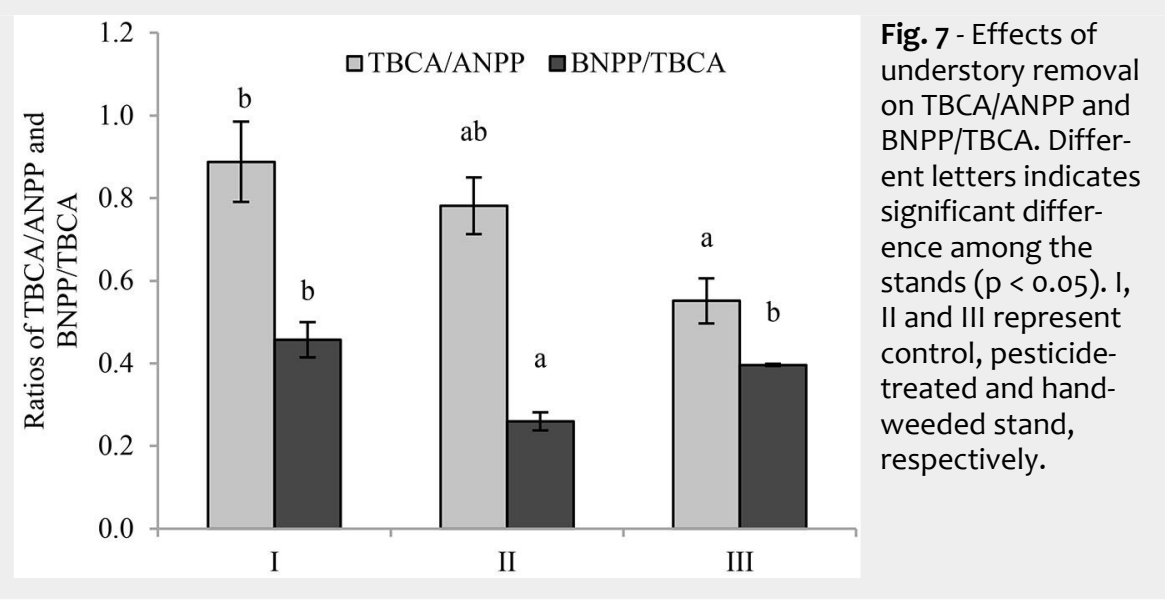

stand biomass. These ratios were higher than that of other forest types $(1.6 \%$ for mature pines and $2.1 \%$ for 70 -year oaks with corresponding stand biomass of 169 and $177 \mathrm{t} \cdot \mathrm{ha}^{-1}$, respectively - Yuste et al. 2005, Berhongaray et al. 2013). Because the fine root biomass was relatively high in Moso bamboo forests, while the total stand biomass was relatively low $\left(29-40 \mathrm{t} \mathrm{ha}^{-1}\right)$, the stand biomass remained in a dynamic balance with stand development due to its special biological characteristics (Zhou \& Jiang 2004b). However, our results were similar to a previous study in a Moso bamboo forest (7.7 t ha-1 - Fan et al. 2009), as well in a Pleioblastus amarus bamboo forest (5.3-8.2 t ha-1 - Tu et al. 2010). These results suggest that Moso bamboo has its own biological strategy to meet its required nutrient uptake from the soil in order to maintain high stand productivity despite the large scale timber harvesting.

The strong relationship between fine root biomass and production indicates that fine root biomass was the most important factor for explaining the variation in fine root production. This result is consistent with a meta-analysis using an up-to-date global database covering fine root biomass and production that found that fine root biomass could explain $53 \%$ of the variation in fine root production (Finér et al. 2011b).

Mean fine root turnover ranged from 0.5$0.6 \mathrm{a}^{-1}$, which was similar to that in an Asian white birch forest $\left(0.51 \mathrm{a}^{-1}\right.$, fine roots $<2$ a mixed Populus tremuloides forest ( $0.62 \mathrm{a}^{-1}$ - Yuan \& Chen 2012). However, the value was lower than that in fast-growing poplar plantations ( 2.3 and $2.5 \mathrm{a}^{-1}$ - Berhongaray et al. 2013), a Chinese cork oak forest (1.21 $\mathrm{a}^{-1}$ Ma et al. 2012), and a Fokienia hodginsii forest $\left(1.47 \mathrm{a}^{-1}\right)$.

The large differences in measured fine root turnover may be due to species differences, since the fine root turnover of broad-leaf forests was found to be higher than that of needle-leaf forests (Yuan \& Chen 2010). Alternately, they may be due to different definitions of fine root diameter. Definitions of the maximum diameters of fine roots vary from $0.5 \mathrm{~mm}$ to $10 \mathrm{~mm}$ (Vogt et al. 1986, Nadelhoffer \& Raich 1992, Vogt et al. 1995), although it is most commonly 1-5 mm (Vogt et al. 1995, Chen et al. 2004, Finér et al. 2011a). Previous studies have shown that fine roots with a smaller diameter have higher turnover than larger roots because they have stronger metabolic activity and a shorter life span (Pregitzer et al. 2002, Xiao et al. 2008). For example, the turnover of $<1 \mathrm{~mm}$ roots was higher than that of $1-2 \mathrm{~mm}$ roots ( 0.63 vs. $0.39 \mathrm{a}^{-1}$ ) in an Asian white cork oak forest (Xiao et al. 2008). Another possible reason for different measurements of fine root turnover may be the application of different methods. Based on a meta-analysis, Gill \& Jackson (2000) calculated the fine root turnover as the ratio of annual root pro- $\mathrm{mm}$ - Xiao et al. 2008) and close to that in 
duction and maximum root biomass, which could potentially lead to lower root turnover. As a result, the turnover was as low as $0.1 \mathrm{a}^{-1}$ for total roots and $0.56 \mathrm{a}^{-1}$ for fine roots. These two values are lower than the more recently reported measurements, defined as the ratio of mean root production and mean annual biomass, rather than maximum biomass, of $1.21 \mathrm{a}^{-1}$ for temperate forests and $1.44 \mathrm{a}^{-1}$ for tropical forests in the review of Finér et al. (2011b). Similarly, Berhongaray et al. (2013) found that fine root turnover ranged from 1.5 to $2.5 \mathrm{a}^{-1}$ after comparing different approaches in poplar forests. Our results were also lower than the reported value in a Moso bamboo forest in Hunan Province, China (Fan et al. 2009). We partly attribute such deviation to methodological differences, as Fan et al. (2009) used the improved max-min method that considered both live mass and necromass. Summing the live mass and necromass leads to higher root production estimates than using just the live root biomass (Berhongaray et al. 2013), so the failure to separate live and necromass in our study could result in lower fine root turnover compared to Fan et al. (2009). Therefore, the standardization of the maximum fine root diameter and the measurement method would improve comparisons of fine root turnover.

\section{Total belowground carbon allocation}

Although many management practices are commonly conducted to improve the timber output in Moso bamboo forests ( $\mathrm{Li}$ et al. 2013), there is a lack of knowledge about the effects of these practices on TBCA. This study is the first attempt to estimate TBCA in the Moso bamboo forest relating to understory removal. TBCA (calculated from the component cumulative approach) ranged from 417.7 to $486.9 \mathrm{~g} \mathrm{C}$ $\mathrm{m}^{-2} \mathrm{a}^{-1}$, and there was no significant difference among the three stands, indicating that understory removal had no effects on belowground carbon allocation. Although higher fine root and coarse root production was found in stand I and stand III, this was compensated for by the significantly higher root respiration in stand II $(p<0.05$ - Tang 2012).

Consistent with other reported results in forest ecosystems (Raich \& Nadelhoffer 1989, Davidson et al. 2002), TBCA was higher than the carbon pool in the litter in the three stands. This highlights the importance of TBCA in global carbon modeling. The ratio of BNPP to TBCA is a key process in modeling ecosystem and belowground carbon cycles; however, the assumed ratio of 0.5 has been widely used due to the lack of BNPP and TBCA data (McDowell et al. 2001, Giardina et al. 2003). The BNPP/TBCA of stand I (unmanaged stand) was 0.46, which generally agreed with the constant value in modeling ecosystem and belowground carbon cycle. However, BNPP/TBCA was 0.26 for stand II and 0.40 for stand III, which were much lower than the constant value of 0.5 . These results highlight the importance of including forest management in modelling the belowground carbon cycle.

The strong correlation between the fine root production and TBCA, combined with little or no correlation between fine root biomass, coarse root biomass, and production, suggests that fine root production is a better indicator of changes in TBCA, as it reflects the process of fine root dynamics that is regenerated during a certain time period through the process of new root growth replacing the loss from root death. This result is highly consistent with previous reports (Kurz et al. 1996, Gill \& Jackson 2000, Yuan \& Chen 2013).

The values of TBCA were comparable to those of a Chinese fir plantation in subtropical China (404 g C m${ }^{-2} \mathrm{a}^{-1}$ - Chen et al. 2005) and a Metrosideros polymorpha dominated forest (417 g C m ${ }^{-2} \mathrm{a}^{-1}$ - Raich 1998). The values were also in the range of reported TBCA values of main forest types (146-2510 g C m$\left.~^{-2} \mathrm{a}^{-1}\right)$, but lower than the average TBCA (921.7 $\left.\mathrm{g} \mathrm{C} \mathrm{m}^{-2} \mathrm{a}^{-1}\right)$. The TBCA was also lower than that of a Castanopsis kawakamii forest (842.6 $\mathrm{g} \mathrm{C} \mathrm{m}^{-2} \mathrm{a}^{-1}$ - Chen et al. 2005), a Eucalyptus saligna forest (1880 g C m $\mathrm{a}^{-1}$ - Giardina \& Ryan 2002), and a Pseudotsuga menziesii forest (710-733 g C $\mathrm{m}^{-2} \mathrm{a}^{-1}-$ McDowell et al. 2001). The divergence may be due to the difference in forest types. A meta-analysis found that the average TBCA was in the order of boreal forests < temperate forests < tropical forests (Raich \& Nadelhoffer 1989, Chen et al. 2007). To maintain aboveground production, more carbon is allocated belowground in tropical forests (Raich \& Nadelhoffer 1989). Alternately, the difference may be due to the stage of stand development. For example, the TBCA of an old Chinese fir plantation (88-year) was significantly lower than the TBCA in mature (41year) and middle-aged (21-year) Chinese fir plantations (Chen et al. 2008). Similarly, the TBCA in a fast-growing Eucalyptus plantation linearly decreased with stand age (Giardina \& Ryan 2002). However, how TBCA changes with increasing years of management is still unclear, because in our study we only estimated the TBCA in an "on-year" Moso bamboo forest, and the two management practices both began in 2000. The Moso bamboo forest is a special forest type with mixed ages due to the establishment of new bamboos every year, making it difficult to determine the stand age.

The TBCA calculated from the mass balance approach ranged from 498.4 to 679.2 g C m${ }^{-2} a^{-1}$, which was $23 \%$ higher than that from component cumulative approach on average (Fig. 5). The result might violate the assumptions that the stands were stable and there were no carbon changes in the mineral soil, litter, or roots (Raich \& Nadelhoffer 1989). However, there were no direct data in our study to qualify the carbon changes in the mineral soil, litter, and roots, so we could not estimate the effects of these changes on the TBCA. Similar to our findings, Chen et al. (2005) found that the TBCA measured by the component cumulative approach was $26 \%$ and $28 \%$ lower than that of the mass balance approach in a Chinese fir plantation and a Castanopsis kawakamii forest, respectively. The authors attributed this to the increase in carbon changes in fine roots and coarse roots (Chen et al. 2005). The trenching method was used to partitioning the root respiration, which could have underestimated root respiration when the roots in the trenched subplot did not die completely, especially in the first few months (Hanson et al. 2000). As a result, this could potentially underestimate the TBCA.

Besides the mass balance approach, Raich \& Nadelhoffer (1989) also proposed a universal model relating TBCA to litter biomass as expressed by: TBCA $=1.92 \cdot \mathrm{LF}+330$ $\left(R^{2}=0.52 ; n=30 ; p<0.001\right)$, where $L F$ is the litter carbon $\left(\mathrm{g} \mathrm{C} \mathrm{m}^{-2} \mathrm{a}^{-1}\right)$. If the relationship was applied to our data, TBCA would be two-fold higher than our calculated results. This indicates that the global pattern is not applicable in the Moso bamboo forest in our study area. This has already been confirmed by previous studies (Gower et al. 1996, Nadelhoffer et al. 1998, Davidson et al. 2002) that the relationship is not necessarily applicable to small-scale estimation. Therefore, these results indicate that method selection is extremely important for the precise estimation of TBCA, since the belowground process is extremely complex, but TBCA plays a critical role in the global carbon cycle.

\section{Conclusions}

This study evaluated the effects of understory removal on fine root production, turnover, and TBCA in the infrequently studied Moso bamboo forests. This could contribute to our understanding of the belowground carbon process in these forests and global carbon cycling. Understory removal had no significant effects on fine root turnover and TBCA, but it significantly reduced the fine root biomass and production. The strong relationship between fine root production and turnover and TBCA indicated that fine root production was the main contributor to belowground carbon dynamics. Different methods could generate different estimates of fine root production and TBCA, indicating that refining and improving the methods to estimate the accuracy of root turnover and TBCA will be important for understanding the controls on fine root turnover and belowground carbon allocation. However, our study was only conducted in "on-year" Moso bamboo forests, and further studies are required to determine the effects of stand management on fine root turnover and TBCA change in "off-year".

\section{Acknowledgments}

This study was supported by the " 948 
project" of the State Forest Administration (2013-4-70), the special research fund of the International Center for Bamboo and Rattan (1632013010), the Special Funds for Forestry Public Industry Research (201104 008). The authors would like to thank Qingbiao $\mathrm{Xu}$ for carrying fieldwork and lab work, and Jin $\mathrm{Yu}$, Chuxin Shen for support of fieldwork. We would like to express our thanks to the anonymous reviewers whose suggestions contributed to improve the manuscript.

\section{References}

Bauhus J, Bartsch N (1996). Fine-root growth in beech (Fagus sylvatica) forest gaps. Canadian Journal of Forest Research 26: 2153-2159. - doi: 10.1139/X26-244

Berhongaray $\mathrm{G}$, Janssens IA, King JS, Ceulemans $R$ (2013). Fine root biomass and turnover of two fast-growing poplar genotypes in a shortrotation coppice culture. Plant and Soil 373: 269-283. - doi: 10.1007/s11104-013-1778-x

Brassard BW, Chen HYH, Bergeron Y (2009). Influence of environmental variability on root dynamics in Northern Forests. Critical Reviews in Plant Sciences 28: 179-197. - doi: 10.1080/ 07352680902776572

Brunner I, Bakker MR, Björk RG, Hirano Y, Lukac $M$, Aranda $X$, Eldhuset TD, Helmisaari HS, Jourdan C, Konôpka B, López BC, Miguel Pérez C, Persson H, Ostonen I (2013). Fine-root turnover rates of European forests revisited: an analysis of data from sequential coring and ingrowth cores. Plant and Soil 362: 357-372. - doi: 10.1007/ S11104-012-1313-5

Chen WJ, Zhang QF, Cihlar J, Bauhus J, Price DT (2004). Estimating fine-root biomass and production of boreal and cool temperate forests using aboveground measurements: a new approach. Plant and Soil 265: 31-46. - doi: 10.1007/ s11104-005-8503-3

Chen G, Yang Y, Qian W, Gao R, Niu Z, Han Y (2005). Total belowground carbon allocation in Castanopsis kawakamii and Chinese fir plantations in subtropical area of China. Acta Ecologica Sinica 25: 2824-2829. [in Chinese with English abstract]

Chen G, Yang Y, Liu L, Li X, Zhao Y, Yuan Y (2007). Research review on total belowground carbon allocation in forest ecosystems. Journal of Subtropical Resources and Environment 2: 34-42. [in Chinese with English abstract]

Chen G, Yang Y, Gao R, Xie J, Yang Z, Mao Y (2008). Changes in belowground carbon allocation in a Chinese fir chronosequence in Fujian Province. Journal of Plant Ecology (Chinese version) 32: 1285-1293 [in Chinese with English abstract]

Chen XG, Zhang XQ, Zhang YP, Booth T, He XH (2009). Changes of carbon stocks in bamboo stands in China during 100 years. Forest Ecology and Management 258: 1489-1496. - doi: 10.1016/j.foreco.2009.06.051

Davidson EA, Savage K, Bolstad P, Clark DA, Curtis PS, Ellsworth DS, Hanson PJ, Law BE, Luo Y, Pregitzer KS, Randolph JC, Zak D (2002). Belowground carbon allocation in forests estimated from litterfall and IRGA-based soil respiration measurements. Agricultural and Forest Meteorology 113: 39-51. - doi: 10.1016/So168-
1923(02)00101-6

Fan S, Xiao F, Wang S, Su W, Yu X, Shen Z (2009). Fine root biomass and turnover in Moso Bamboo plantation in Huitong Forest Station, Hunan province. Scientia Silvae Sinicae 45: 1-6. [in Chinese with English abstract]

Finér L, Ohashi M, Noguchi K, Hirano Y (2011a). Factors causing variation in fine root biomass in forest ecosystems. Forest Ecology and Management 261: 265-277. - doi: 10.1016/j.foreco.20 10.10.016

Finér L, Ohashi $M$, Noguchi K, Hirano $Y$ (2011b). Fine root production and turnover in forest ecosystems in relation to stand and environmental characteristics. Forest Ecology and Management 262: 2008-2023. - doi: 10.1016/j.for eco.2011.08.042

Fu J (2000). Moso bamboo in China. ABS Magazine 21: 12-17.

Fu J (2001). Chinese Moso bamboo: its importance. Bamboo 22: 5-7.

Giardina CP, Ryan MG (2002). Total belowground carbon allocation in a fast-growing Eucalyptus plantation estimated using a carbon balance approach. Ecosystems 5: 487-499. - doi: 10.1007 /s10021-002-0130-8

Giardina CP, Ryan MG, Binkley D, Fownes JH (2003). Primary production and carbon allocation in relation to nutrient supply in a tropical experimental forest. Global Change Biology 9: 1438-1450. - doi: 10.1046/j.1365-2486.2003.0055 8.x

Gill RA, Jackson RB (2000). Global patterns of root turnover for terrestrial ecosystems. New Phytologist 147: 13-31. - doi: 10.1046/j.1469-8137. 2000.00681.x

Goff NL, Ottorini J-M (2001). Root biomass and biomass increment in a beech (Fagus sylvatica L.) stand in North-East France. Annals of Forest Science 58: 1-13. - doi: 10.1051/forest:2001104

Gower ST, Pongracic S, Landsberg JJ (1996). A global trend in belowground carbon allocation: can we use the relationship at smaller scales? Ecology 77: 1750-1755. - doi: 10.2307/2265780 Hanson PJ, Edwards NT, Garten CT, Andrews JA (2000). Separating root and soil microbial contributions to soil respiration: a review of methods and observations. Biogeochemistry 48: 115-146. - doi: 10.1023/a:1006244819642

Jackson RB, Mooney HA, Schulze E-D (1997). A global budget for fine root biomass, surface area, and nutrient contents. Proceedings of the National Academy of Sciences USA 94: 73627366. - doi: 10.1073/pnas.94.14.7362

Kurz WA, Beukema SJ, Apps MJ (1996). Estimation of root biomass and dynamics for the carbon budget model of the Canadian forest sector. Canadian Journal of Forest Research 26: 1973-1979. - doi: 10.1139/X26-223

Law BE, Ryan MG, Anthoni PM (1999). Seasonal and annual respiration of a ponderosa pine ecosystem. Global Change Biology 5: 169-182. doi: 10.1046/j.1365-2486.1999.00214.x

Li YF, Zhang JJ, Chang SX, Jiang PK, Zhou GM, Fu SL, Yan ER, Wu JS, Lin L (2013). Long-term intensive management effects on soil organic carbon pools and chemical composition in Moso bamboo (Phyllostachys pubescens) forests in subtropical China. Forest Ecology and Management 303: 121-130. - doi: 10.1016/j.foreco.2013. 04.021
Liu J, Jiang PK, Wang HL, Zhou GM, Wu JS, Yang $\mathrm{F}$, Qian XB (2011). Seasonal soil $\mathrm{CO}_{2}$ efflux dynamics after land use change from a natural forest to Moso bamboo plantations in subtropical China. Forest Ecology and Management 262: 1131-1137. - doi: 10.1016/j.foreco.2011.06.015 Ma C, Zhang W, Wu M, Xue Y, Ma L, Zhou J (2012). Effect of aboveground intervention on fine root mass, production, and turnover rate in a Chinese cork oak (Quercus variabilis Blume) forest. Plant and Soil 368: 201-214. - doi: 10.1007/ s11104-012-1512-0

Majdi H, Pregitzer K, Morén A-S, Nylund J-E (2005). Measuring fine root turnover in forest ecosystems. Plant and Soil 276: 1-8. - doi: 10.10 07/s11104-005-3104-8

McClaugherty CA, Aber JD, Melillo JM (1982). The role of fine roots in the organic matter and nitrogen budgets of two forested ecosystems. Ecology 63: 1481-1490. - doi: 10.2307/1938874

McDowell NG, Balster NJ, Marshall JD (2001). Belowground carbon allocation of Rocky Mountain Douglas-fir. Canadian Journal of Forest Research 31: 1425-1436. - doi: 10.1139/x01067

Nadelhoffer KJ, Raich JW (1992). Fine root production estimates and belowground carbon allocation in forest ecosystems. Ecology 73: 1139-1147. - doi: 10.2307/1940664

Nadelhoffer KJ, Raich JW, Aber JD (1998). A global trend in belowground carbon allocation: Comment. Ecology 79: 1822-1825. - doi: 10.1890/ 0012-9658(1998)079[1822:AGTIBC]2.0.CO;2

Pregitzer KS, King JS, Burton AJ, Brown SE (2000). Responses of tree fine roots to temperature. New Phytologist 147: 105-115. - doi: 10.1046/j.1469-8137.2000.00689.x

Pregitzer KS, DeForest JL, Burton AJ, Allen MF, Ruess RW, Hendrick RL (2002). Fine root architecture of nine North American trees. Ecological Monographs 72: 293-309. - doi: 10.2307/310 0029

R Core Team (2014). R: a language and environment for statistical computing. R Foundation for Statistical Computing, Vienna, Austria. URL. [online] URL: http://www.R-project.org/ Raich JW, Nadelhoffer KJ (1989). Belowground carbon allocation in forest ecosystems: global trends. Ecology 70: 1346-1354. - doi: 10.2307/ 1938194

Raich JW (1998). Aboveground productivity and soil respiration in three Hawaiian rain forests. Forest Ecology and Management 107: 309-318. doi: 10.1016/S0378-1127(97)00347-2

Ryan MG, Lavigne MB, Gower ST (1997). Annual carbon cost of autotrophic respiration in boreal forest ecosystems in relation to species and climate. Journal of Geophysical Research: Atmospheres 102: 28871-28883. - doi: 10.1029/97jdo1 236

State Forestry Administration (2014). Report for Chinese forest resource - The $8^{\text {th }}$ National Forest inventory. China Forestry Publishing House, Beijing, China. pp. 94. [in Chinese]

Tang XL (2012). Research on characteristic of soil respiration in different managed Phyllostachy edulis forests, Mufu Mountain, China. M.sc. thesis, Chinese Academy of Forestry, Beijing, China, pp. 105.

Tang X, Fan S, Qi L, Liu G, Guan F, Du M, Shen C (2012). Effect of different managements on car- 
bon storage and carbon allocation in Moso Bamboo forest (Phyllostachys pubescens). Acta Agriculturae Universitatis Jiangxiensis 34: 736742. [in Chinese with English abstract]

Tang X, Fan S, Qi L, Guan F, Cai C, Du M (2015). Soil respiration and carbon balance in a Moso bamboo (Phyllostachys heterocycla (Carr.) Mitford cv. Pubescens) forest in subtropical China. iForest - Biogeosciences and Forestry 8 (5): 606-614. - doi: 10.3832/ifor1360-007

Tu L, Hu T, Zhang J, He Y, Tian X, Xiao Y (2010). Effects of simulated nitrogen deposition on the fine root characteristics and soil respiration in a Pleioblastus amarus plantation in rainy area of West China. The Journal of Applied Ecology 21: 2472-2478. [in Chinese with English abstract]

Vogt KA, Grier CC, Vogt DJ (1986). Production, turnover, and nutrient dynamics of above- and belowground detritus of world forests. In: "Advances in Ecological Research" (MacFadyen A, Ford ED eds). Academic Press, London, UK, pp. 303-377. [online] URL: http://books.google. com/books?id=Lezo6XJVKloC

Vogt K, Vogt D, Palmiotto P, Boon P, Hara J, Asbjornsen H (1995). Review of root dynamics in forest ecosystems grouped by climate, climatic forest type and species. Plant and Soil 187: 159219. - doi: $10.1007 /$ bfoo017088

Wang GP, Innes JL, Dai SY, He GH (2008). Achieving sustainable rural development in Southern China: the contribution of bamboo forestry. International Journal of Sustainable Development and World Ecology 15: 484-495. - doi:
10.3843/Susdev.15.5:9

Xiao CW, Sang WG, Wang R-Z (2008). Fine root dynamics and turnover rate in an Asia white birch forest of Donglingshan Mountain, China. Forest Ecology and Management 255: 765-773. doi: 10.1016/j.foreco.2007.09.062

Xu QF, Jiang PK, Xu ZH (2008). Soil microbial functional diversity under intensively managed bamboo plantations in southern China. Journal of Soils and Sediments 8: 177-183. - doi: 10.1007/ s11368-008-0007-3

Yuan ZY, Chen H (2010). Fine root biomass, production, turnover rates, and nutrient contents in boreal forest ecosystems in relation to species, climate, fertility, and stand age: literature review and meta-analyses. Critical Reviews in Plant Sciences 29: 204-221. - doi: 10.1080/0735 2689.2010.483579

Yuan ZY, Chen HYH (2012). Fine root dynamics with stand development in the boreal forest. Functional Ecology 26: 991-998. - doi: 10.1111/j.13 65-2435.2012.02007.x

Yuan ZY, Chen HYH (2013). Effects of disturbance on fine root dynamics in the boreal forests of Northern Ontario, Canada. Ecosystems 16: 467-477. - doi: 10.1007/s10021-012-9623-2

Yuste JC, Konôpka B, Janssens IA, Coenen K, Xiao CW, Ceulemans R (2005). Contrasting net primary productivity and carbon distribution between neighboring stands of Quercus robur and Pinus sylvestris. Tree Physiology 25: 701-712. - doi: 10.1093/treephys/25.6.701

Zhang WR, Yang GY, Tu XN, Zhang P (1999).
Determination of organic matter in forest soil and calculation carbon-nitrogen ratio. In: "Standards of forest soil measurement" (Zhang WR, Yang GY, Tu XN, Zhang P eds). China Standard Press, Beijing, China, pp. 105-108. [in Chinese] Zhang HX, Zhuang SY, Sun B, Ji HB, Li CM, Zhou S (2014). Estimation of biomass and carbon storage of moso bamboo (Phyllostachys pubescens Mazel ex Houz.) in southern China using a diameter-age bivariate distribution model. Forestry 87: 674-682. - doi: 10.1093/forestry/cpuo28

Zhou G, Jiang P (2004a). Density, storage and spatial distributbion of carbon in Phyllostachy pubescens forest. Scientia Silvae Sinicae 40: 2024. [In Chinese with English abstract]

Zhou GM, Jiang PK (2004b). Density, storage and spatial distribution of carbon in Phyllostachy pubescens forest. Scientia Silvae Sinicae 40: 20-24. [In Chinese with English abstract] Zhou GM, Xu JM, Jiang PK (2006). Effect of management practices on seasonal dynamics of organic carbon in soils under bamboo plantations. Pedosphere 16: 525-531. - doi: 10.1016/S10 02-0160(06)60084-2

Zhou G, Jiang P, Xu Q (2010). Carbon sequestration and transform in bamboo ecosystem. Science Press, Beijing, China, pp. 105-137.

Zhou BZ, Li ZC, Wang XM, Cao YH, An YF, Deng ZF, Letu GR, Wang G, Gu LH (2011). Impact of the 2008 ice storm on moso bamboo plantations in southeast China. Journal of Geophysical Research-Biogeosciences 116: GooHo6. - doi: 10.1029/2009jg001234 